Van de Walle S., Kampen, J. K. \& Bouckaert, G. (2005). Deep impact for high impact agencies? Assessing the role of bureaucratic encounters in evaluations of government, In: Public Performance and Management Review, 28(4): $532-549$

Deep Impact for High Impact Agencies? Assessing the Role of Bureaucratic Encounters in Evaluations of Government

Steven Van de Walle, Jarl K. Kampen and Geert Bouckaert

Public Management Institute, Katholieke Universiteit Leuven 


\begin{abstract}
Public sector reforms often focus on high impact agencies in order to restore trust in government and in public administration. Using an in-person survey on citizens' attitudes towards public services, we test what public agencies contribute to citizens' general image of government. It is shown that general measures of satisfaction with the functioning of public services contain more than just an evaluation of bureaucratic encounters. Political factors influence this assessment. Specific evaluations of service quality can differ substantially from attitudes towards public services at large. Therefore, low trust in government, a negative attitude towards public administration at large and a positive image of many specific public services may coexist.
\end{abstract}

Keywords: trust in government; public services; service delivery; high-impact agencies; public opinion; client satisfaction. 
Deep Impact for High Impact Agencies? Assessing the Role of Bureaucratic Encounters in Evaluations of Government ${ }^{1}$

“How can people trust government to do big things if we can't do little things like answer the phone promptly and politely?", ask Clinton and Gore in the Blair House papers (Clinton \& Gore, 1997, p. ix). Recent government modernization rhetoric reflects the opinion that failing government performance is at the basis of citizens' distrust in government. This is a topic that is receiving increasing attention, not only among academics (Pollitt \& Bouckaert, 2000, pp. 123-6; Bok, 2001), but also in government institutions and think-tanks.

An increasing number of government reports are looking into the relationship between the performance of public services and citizens' trust. A State Services Commission report in New Zealand looked into the relationship between citizens' trust and government performance on a number of key policy areas (Barnes \& Gill, 2000), as did a report in Western Australia (Ryan, 2000). The Canadian government ordered reviews of survey data on user satisfaction and citizen trust (Sims, 2001; Stoyko, 2002). In the introduction to the Government Performance and Results Act it is stated that "waste and inefficiency in Federal programs undermine the confidence of the American people in the Government [...]" (Government Performance and Results Act, 1993). Many OECD documents refer in a similar fashion to the relationship between the functioning of the public sector and public trust (see e.g., OECD, 2000). The National Partnership for Reinventing Government (NPR) in the US is even bolder in its claims:

After a 30-year decline, public trust in the federal government is finally increasing. When last measured by the University of Michigan in 1998, the public's trust in government had nearly doubled within a four-year period to 40 percent. While this 
cannot be totally attributed to the results of reinvention, NPR believes reinvention has made an important contribution in raising the public's trust in the government and creating a better workplace for federal employees. (National Partnership for Reinventing Government, 2001).

These discourses have taken on a life of their own, and have had a considerable impact on governments. (Proposed) administrative reforms are often motivated not by mere efficiency considerations, but by a wish to create a government "that can be trusted", "that really matters" and "that acts in accordance with citizens' wishes". Many quality improvement initiatives therefore follow a user-centered logic, in that they focus on those services that are supposed to have a high impact on citizens' lives. E-government's fascination for portals and the front office is just one example (Kampen \& Snijkers, 2003). Most administrative reform projects put citizens' image of specific public services and agencies at the center of efforts to improve citizens' general image of government (Van de

Walle \& Bouckaert, 2003). Citizens who make a positive assessment of their encounters with public services and the public administration are said to have a generally positive image of the public sector and government, which is commonly, correctly or not, described as "trust".

Using Belgian survey data, we explore the role of bureaucratic encounters with socalled "high impact agencies" in citizens' evaluation of public sector functioning, and the spill-over of these attitudes to evaluations of government at large ("trust in government").

\section{Restoring Trust}

A number of scandals in the 1990s and a substantial amount of slack in public services plunged Belgium into a confidence crisis and stimulated the public administration and the government to embark upon ambitious reforms of the public administration, both at 
the Belgian federal level and at the Flemish regional level. Restoring trust was one of the catchphrases in the reforms. Within the framework of these administrative reforms at the Flemish level, our research group was asked to look into the relationship between the quality of public services, user satisfaction, and citizens' trust in government. In other words, does improving public services contribute to restoring citizens' trust in government, and, if “yes", what services are indispensable? Three surveys titled "Werken aan de Overheid" ("Working on Government") were organized. In this article, we only use data from the 2002 in-person survey. 1248 citizens residing in the Flemish region (5.97 million inhabitants) participated in this survey that had a response rate of $68.2 \%$. Two other surveys were organized by mail $(\mathrm{N}=5500$, response rate $=63.5 \%)$, but will not be used here. The survey was composed of four main parts:

1. Socio-demographics

2. Citizens and public services

3. Citizens and politics

4. Citizens and society

Though the main part of the survey dealt with experiences and evaluations of specific public services, it also contained variables on political trust, voting behaviour, individualism, traditionalism, ethnocentrism, social capital and so on.

\section{High Impact Agencies}

In 1998, the National Partnership for Reinventing Government shifted its focus from a government-wide reform initiative to an initiative aimed at 32 High Impact Agencies (National Partnership for Reinventing Government, 2000) ${ }^{2}$. Approximately $80 \%$ of the NPR's energy would go to these 32 agencies in order to:

- Restore trust 
- Improve performance

- Cut costs

Selection of these agencies was made based on criteria of use and visibility: together, these 32 agencies serve $90 \%$ of the government's customers. Most of these agencies were also included in the American Customer Satisfaction Index, which allowed for measurement of the effects of the reforms (Fornell, 2000). With this initiative, the NPR supposed that reforms in these agencies would have the biggest impact on trust. This claim is based on visibility and use of these services, while the importance of these agencies for customers, or customers' dependency on them, are disregarded as criteria to determine the "high" impact of agencies. Additionally, if one looks at the list of agencies, one notices the absence of governmental agencies such as police and schools. The reason for this is that the NPR was a federal initiative. Therefore, even though a list of HIAs had been developed, many of the High Impact Agencies are missing. If the HIA approach was a correct and complete one, it would be possible to calculate separately what influence each institution has on the perception of the government in general.

No similar listing of High Impact Agencies exists in Belgium. In the e-government strategy a number of service delivery clusters have been identified that combine services related to important life-events of citizens: building a house, retirement, having children and so on. In the 1999 Election Studies Belgians ranked child protection as one of the most important topics determining their vote (Meersseman, Billiet, Depickere, \& Swyngedouw, 2001). This clearly is an issue that would not feature as a high impact issue in other countries, and it was clearly not an issue in the early 90s. Food safety also became an important topic in 1999, while employment was one of the main issues in 2003. A crisis in the mid-1990s managed to push the performance of the police and the courts to the center of citizens' perception of government. 
The use of the term "high impact agencies" is very much motivated by the desire to achieve "quick wins" by focusing on those services having many users or on front-offices instead of back offices. Actions targeting HIAs are thus said to create goodwill among citizens and civil servants, but are not necessarily a guarantee for sustainable reform. Referring to HIAs is often part of a political strategy, and therefore dominantly serves as a handy anchor for communicating reform rather than for steering it (see also Kettl, 1998).

\section{Defining High Impact Agencies}

The high impact agencies approach implies that public services that are important to citizens, or with which citizens have a high contact-ratio, determine their general image of public services, and, consequently of government. The reform rhetoric on high impact agencies contains a strong normative component, due to these agencies' prominent place in public sector reform. Emphasis on those services having a high (and direct) impact on citizens' lives is said to be the fastest way for increasing citizens' trust in government. These approaches put a strong emphasis on public services rather than on politics, and on government rather than on society in the process of restoring trust. Furthermore, they tend to reduce government to a mere summation of agencies and public services.

Though the high impact definition is a very attractive one at first, it is problematic to determine which agencies are exactly high impact ones. The HIA approach tries to deconstruct the multitude of citizen contacts with administrations and public services to a summation and sequence of one-to-one contacts, and the construction of a HIA-list may differ substantively depending on the criteria used. 


\section{A Deconstruction of the Citizen-Government Encounter}

In the high impact philosophy, citizens' bureaucratic encounters exist in a series of separate, consecutive, and conscious experiences with public agencies. In reality, citizens have many encounters with many public services every day, sometimes even without realizing. Therefore, it is not always possible for them to determine where one encounter ends and another begins. Furthermore, many encounters are experienced collectively. This means that citizens' evaluations of public services do not consist of a summation of genuine evaluations of individually experienced performances of a single agency. Though useful for analytical purposes, it is difficult to uphold the deconstruction of citizen-public services encounters into a series of one-to-one experiences. This comment forces us to formulate an additional and alternative hypothesis: citizens' evaluations of public services are not a summation of evaluations of individual-level bureaucratic encounters. Instead, evaluations of public services in general are part of an unspecified general evaluation of government.

\section{Difficulties in Determining the Strength of an Impact}

Determining what services or agencies should be considered high impact is difficult since one can use many criteria for this selection. Furthermore diverse life-styles mean that different people define high-impact agencies differently. Differentiating between types or categories of citizens falls out of the scope of this paper (and our data do not allow for it), so we must resort to criteria that allow for a selection at the macro-level. Using a single criterion such as contact-frequency, the number of customers or size of the budget is insufficient, since such an approach disregards other considerations citizens may have. Citizens can frequently use certain services without being aware of it, and one single contact with an agency may be considered very important. In Table 1 we have constructed a non-exhaustive list of criteria 
that may be used for determining whether a service qualifies as a so-called "high impact agency".

<Table 1 here>

Table 1 suggests that actually testing the importance of citizens' experience with high impact agencies for explaining their attitude towards public services and government at large is problematic, mainly because of the difficulties in determining what high impact agencies are.

\section{Stability of High Impact: The Changing Nature of Trust}

The listing of criteria above suggests that it is not only difficult to establish what the high impact agencies are. The term "high impact agencies" is mainly used in reform discourse, which means that there is very little theoretical support for the concept. Research on trust in government often deals with the role of government outputs in citizens' evaluation of government (Easton, 1965; 1975), but these approaches in general do not reduce government output to that of a number of high impact agencies. Rothstein points out the importance of output institutions to influence trust in general, since citizens have more contact with these compared to the input-side (voting, politicians) (Rothstein, 2001). What outputs citizens look at is neither clear, nor stable. Citizens may have other objects of reference depending on the political system in which they find themselves, their level of political sophistication, their frequency of contact with certain institutions, and so on. As we have tried to show above, the composition of the list of high impact agencies for citizens will no doubt be different for US and for Belgian citizens, and there is good reason to believe that reference objects differ across nations, time, and even between individual citizens. 


\section{Across Nations and Across People}

As mentioned in the previous section, different patterns of use of public services exist for different people. Determining a single high impact agency structure therefore seems to be impossible. We nevertheless believe that this should be possible at the macro-level. Canache et al. (2001) found that while a similar term is used in different nations for tapping attitudes towards government (here it means satisfaction with the functioning of democracy), the substantive content of the item is different. McAllister (1999) found that correlations between levels of confidence in different institutions differ considerably across nations. There is no reason to suppose that citizens in different political systems would perceive their government through the same combination of institutions.

\section{Across Time}

Easton and Dennis (1969) analyzed children's perception of the political system, and found that the institutions, which were considered important changed as they grew older. In political systems, certain institutions may at times be considered more important, due to evolutions in society (e.g. competition protection agencies) or due to crises (e.g. food safety agencies in EU countries as a result of a series of food chain contaminations). Shifts to a "risk society" may give rise to increased importance of control institutions (Beck, 1992). Furthermore, it may be possible for governments to set the agenda and divert attention by pushing certain institutions to the core of citizens' perception of government.

Drafting a list of High Impact Agencies may for the above reasons be difficult. We therefore restrict ourselves to an explorative approach at the macro level by performing an 
analysis of citizens' general attitudes towards government, as a dependent variable, and a series of public services, as independent variables.

\section{Operationalization and Model}

We tested the contribution of experiences with specific public services (bureaucratic encounters) to citizens' evaluation of public services in general. As the reform rhetoric suggests that citizens who experience quality when encountering public services will also evaluate government at large in a positive way, we also tested the contribution of bureaucratic encounters to citizens' trust in government. We fitted identical regression models for two different but related dependent variables. The first one was satisfaction with the functioning of public services and the second was trust in government.

We used a stepwise approach to enter different groups of independent variables in the models. In step one, we entered some basic socio-demographic variables: gender, education, age, income, and degree of urbanization. We learned from previous research on trust that these socio-demographics in most cases do not make a large contribution to the explanatory value of the models (Elchardus \& Smits, 2002; Kampen \& Molenberghs, 2002), but we included them to control for possible effects.

In step two, we added a number of public services. Some of the services are clearly public, others have strong links to the public sector: police, courts, Belgian Post, primary education, refuse collection, public transport, hospitals, elderly care, Belgian Railways, public television, municipal administration and the electricity company. Participants in the survey had to respond to the question "Is the image you have of these services and institutions positive or negative?" on a 1 (very negative) to 5 (very positive) scale. 
In step three, we broadened the analysis by adding a number of government-related professions: police officer, refuse collector, judge, teacher, bus driver, train conductor, mailman, post office worker, prison ward, military and fire-fighter. By using professions and not services, this approach is different from the previous, and it allows us to broaden our scope. Unfortunately, the survey data do not allow us to fine-tune the model by adding data on contact frequency in step two and three.

In step four, we added citizens' image of civil servants as a broad category, as well as citizens' image of politicians.

Ordinal regression analysis was used, because the dependent variables were measured using an ordinal scale (McCullagh, 1980). Variables that did not turn out to be significant were not taken to the next step. We only show the final results.

\section{Explaining Satisfaction with Public Services and Trust in Government}

Before answering questions on specific public services, respondents had to answer two general questions, which were used as dependent variables:

- To what extent do you trust government?

- To what extent are you satisfied with the functioning of public services?

Around $43 \%$ of the Flemish respondents were satisfied or very satisfied with the functioning of public services, while $40 \%$ were neither satisfied nor dissatisfied. This left less than $20 \%$ of respondents dissatisfied. For trust in government, the results were somewhat different: here the number of distrusting respondents amounted to almost $30 \%$. Both variables showed a correlation of .434 (Kendall's tau).

$<$ Figure 1 here $>$ 
Our first regression model took satisfaction with the functioning of public services as a dependent variable. Our independent variables were entered in four consecutive steps, as indicated above.

$<$ Table 2 here $>$

Income level was the only socio-demographic that had a weak impact in the first analysis. Its impact vanished later. Police, courts and the mail service were the three most relevant public services in the model. The impact of the former two had already been established in other research (Tyler \& Huo, 2002). The latter was, of course, one of the public services most citizens used daily. Other significant services were public transport and hospitals. Adding a number of professions generated some results, but these were marginal at best. We left teachers' image in the model, but the p value suggested it only had marginal significance or not even that. One remarkable observation was that the image of "the post office worker" was one of the few variables that remained significant, and that it was the only one with a negative value. There was no plausible theoretical explanation available for this phenomenon, even more so because satisfaction with the mail service had a positive sign. Adding civil servants' and politicians' image to the analysis was responsible for a considerable increase in $\mathrm{R}^{2}$. The image of civil servants and politicians turned out to have a solid contribution to the model. The final model had a $\mathrm{R}^{2}$ of .232 (Long, 1997).

The explanatory power of our trust in government model was comparable to that of the satisfaction with the functioning of public services model, but we found some other variables to be significant. As with satisfaction with the functioning of public services, citizens' image 
of politicians was one of the most important contributors to trust in government as well. This variable was responsible for a considerable increase in explained variance. It was more important than most of the public administration items in the questionnaire. The higher the level of education of a respondent, the higher his or her level of trust was. As in the previous model, police and courts were significant as well, as were some other public services. Again, some negative signs appeared in the model.

Our analysis returned a number of findings on our initial hypothesis that stated that citizens' attitude towards a number of "high impact agencies" had a strong impact on their general evaluation of the public sector and government. The first one was that there is not much support for the High Impact Agencies hypothesis. Only some public services seem to have determined general attitudes towards the public sector, notably the courts and the police, whose influence on citizens' trust in government has been ascertained before (Tyler \& Huo, 2002). The other important variables were citizens' image of politicians and civil servants. This came somewhat as a surprise, as it seemed somewhat strange that citizens referred to politicians when evaluating the functioning of public services. Similarly, the image of "civil servant" was present while many specific public sector professions were absent. This suggested that bureaucratic encounters were not that important in the formation of attitudes towards the public sector.

A second observation was that there was surprisingly little difference between both tested models. With some exceptions, explanatory power and composition of the final models for trust in government and satisfaction with the functioning of public services hardly differed. This suggested that these two dependent variables in fact measure the same thing. Citizens' image of politicians was in a central position, and also the rather broad concept of 
"civil servant" figured prominently. Satisfaction with the functioning of public services may therefore not have measured what we think it measured, i.e. an evaluation of bureaucratic encounters.

\section{Evaluations of Service Quality}

If it is true that satisfaction with the functioning of public services did in reality measure a general attitude towards government rather than towards public services, it was not surprising that we found so little influence of specific public services. Goodsell (1985) and others (Katz, Gutek, Kahn, \& Barton, 1977) have suggested that a very general question such as "To what extent are you satisfied with the functioning of public services?" may generate other answers than questions aimed at more specific opinions, because they leave respondents with a broader array of points of reference when constructing their answer. When asked for satisfaction with mail delivery, citizens can in fact only rely on factors related to the delivery of mail and the post office when formulating an answer. Opinions on "public services" at large leaves respondents with a broad array of specific public services to base their opinion on, and invites them to include a large number of elements into their evaluation. Selection of evaluation factors is not necessarily based on rational grounds.

In formulating an opinion, people tend to use the most easily accessible facts and ideas (Zaller, 1996). One negative experience with a single public service may therefore taint the opinion on public services at large. Personal experience is not required in order to formulate an opinion, as one can rely on second-hand experience or rumor (Van de Walle, 2004). Answering a question on "satisfaction with public services" can be influenced by factors that have nothing to do with an evaluation of the functioning of public services, but with a general attitude towards government. The array of potential points of reference is therefore as broad as it is in the case of a question on trust in government. This seems to be 
partly confirmed by the impact of parameters such as the image of politicians and image of civil servants in our model for satisfaction with the functioning of public services.

For these reasons, we have to look for a more specific dependent variable that does not "invite" respondents to deviate in their answer to aspects that are not directly related to the functioning of public services. The survey also contained a question where respondents had to indicate their opinion on a number of characteristics of government staff. It concerned very specific attributes that did not invite respondents to bring in factors into their evaluation that were not directly related. Table 3 shows the results.

$<$ Table 3 here $>$

The seven variables were entered in a principal components analysis, and the analysis returned one single factor explaining $53 \%$ of the total variance. We shall use the term evaluation of service quality in the remainder of the article. We now use the factor scores for each observation as the dependent variable in our regression. The same variables were entered following the same procedure as selection, but instead of an ordinal regression we applied a linear regression, due to the nature of the dependent variable.

$<$ Table 4 here $>$

As in the other models, satisfaction with the police and the image of the courts remained significant. The most important contribution to the model was citizens' image of the municipal administration. This was a surprising observation, as this item had no influence at all in the model on satisfaction with the functioning of public services. The disappearance of the image of politicians, while the image of civil servants remained in the model, was a 
very interesting observation, since the image of the politicians was a very important parameter in the satisfaction with the functioning of public services model and of course in the trust in government model.

The findings suggested that a specific evaluation of service delivery quality was to a large extent based on service encounters, whereas an evaluation of public services at large seemed to rely on more generic criteria. Most of the significant variables in the model were services with a high impact. Most of them were visible at the local level: the municipal administration was one of the few traditional "bureaucracies" citizens had contact with on a regular basis. Still, the image of civil servants remained significant in the model, as did that of the courts, even though specific encounters were limited. This shows that at least some "general knowledge" of the public administration "contaminated" what could otherwise be regarded as a genuine evaluation of public services.

\section{Summary of the Findings}

Do attitudes towards specific public services influence one's general attitude towards government and public services? We have tested three different models. All the models were tested using exactly the same independent variables. Dependent variables were satisfaction with the functioning of public services, trust in government and evaluation of service quality respectively. Table 5 provides a summary of our findings and lists the significant parameters in each of the models.

$<$ Table 5 here> 
The differences in significance of the independent variables indicated that a general measure such as satisfaction with the functioning of public services was measuring something different from an evaluation of service quality. The image of the police and the courts had a strong and significant impact in all three models. The image of politicians featured in the trust in government and the satisfaction with the functioning of public services model, while it did not feature in the evaluation of service quality model. This suggests that evaluation of service quality was based on aspects that were directly related to public administration and actual government service delivery, while political factors influenced the satisfaction with the functioning of public services opinion. Experience mattered more in the evaluation of service quality, which was further confirmed by the composition of the list of parameters for this model. It was only in this model that the image of the municipal administration had a significant (and strong) impact. Absence of the municipal administration in the other models was somewhat surprising, since the municipal administration was one of the few "public administrations" (and not just services) most citizens had direct contact with.

A comparison of the three models suggested that using general questions on satisfaction with the functioning of public services is not a valid way for eliciting a genuine evaluation of the functioning of public services. Instead, this method provided us with information on the general attitude towards public services that was not necessarily based on an evaluation of how specific public services function. The strong impact of the image of politicians in the model and the similarities with the trust in government model suggested that citizens also referred to factors other than administrative ones in the formulation of their opinion. 


\section{Conclusions}

Do citizens' evaluations of public services and government agencies influence their general assessment of the public administration and government? Using a general survey on citizens' attitudes towards public administration and government, we have empirically tested the hypothesis implicit in much administrative reform discourse that high impact agencies were the most important determinants of citizens' attitude towards public services and government at large. As "high impact agencies" is a concept that is mainly used in reform rhetoric, we were faced with the difficulty of operationalizing this concept. We can use many intermingling criteria for determining whether an agency actually is a high impact agency, and it is therefore not possible to draw up a definitive list, because its composition may differ depending on the public sector under study. This suggests that despite its usefulness for marketing purposes, an operationalization of high impact agencies is very difficult.

We tested the impact of citizens' attitudes towards specific public services on their general attitude towards public services and towards government. The analysis suggested that satisfaction with the functioning of public services was more than a mere evaluation of the functioning of agencies that compose of the government or the public sector, as many nonbureaucratic factors seem to intervene, notably citizens' image of politicians. A comparison of variables explaining trust in government and those explaining satisfaction with public services revealed many similarities and suggested that both measure, in fact, an identical attitude. Heavy reliance on bureaucratic encounters to explain citizens' attitude towards the public sector, as was done in the high impact agencies approach, ignores these findings.

The general nature of an item such as satisfaction with the functioning of public services invites citizens to draw many factors into their evaluation. It therefore tells us more about their general attitude towards government than about their evaluation of experienced 
bureaucratic encounters. Evaluations of service quality, on the other hand, seemed to rely on respondents' experience with public services, and because of their specificity they were mainly influenced by citizens' attitudes towards specific public services.

Our findings seem to confirm Goodsell's claim that the more specific the object of evaluation, the more positive citizens become towards public services. A general evaluation produces negative results, precisely because citizens can identify with a broader array of negative reference objects. Measuring the impact of public sector reforms is therefore tricky, since improvements in service delivery will not necessarily be reflected in general measures of citizens' trust and satisfaction. Detailed studies of specific aspects of this service delivery relationship, however, may show increases in satisfaction as a result of reforms.

Citizens tend to use the most easily accessible facts and ideas (Zaller, 1996). Since the questions on trust in government directly precede the ones on satisfaction with the functioning of public services, the similarities between both should not surprise us. This may seem to be a trivial finding, without relevance beyond survey methodology, but it is not. In reality, the way citizens discuss government and the public sector is also influenced by context. It seems improbable that specific recent bureaucratic experiences will be the main influencing factors in the formation of attitudes. Instead, citizens adapt the way they speak about public services to the dominant discourse in the group.

Attempts to restore public trust by reinventing the functioning of public services may therefore not generate the desired results, as citizens' attitudes towards specific aspects of service delivery do not necessarily spill over into their general attitude towards government. Achieving quick wins by focusing public sector reforms on certain high impact agencies may 
well not influence citizens' attitudes beyond that towards the specific agency. Low trust in government, a negative attitude towards the public administration at large and a positive image of many public services may coexist. 


\section{References}

Barnes, C., \& Gill, D. (2000). Declining government performance? Why citizens don't trust government. New Zealand: State Services Commission.

Beck, U. (1992). Risk society: towards a new modernity. London: Sage.

Bok, D. (2001). The trouble with government. Cambridge, MA: Harvard University Press.

Canache, D., Mondak, J. J. \& Seligson, M. A. (2001). Meaning and measurement in crossnational research on satisfaction with democracy. The Public Opinion Quarterly, 65(4), 506-529.

Clinton, B., \& Gore, A. (1997). The Blair House papers. S.1.: Diane Publishing Co.

Easton, D. (1975). A re-assessment of the concept of political support. British Journal of Political Science, 5(4), 434-457.

Easton, D. (1965). A systems analysis of political life. New York: Wiley.

Easton, D., \& Dennis, J. (1969). Children in the political system: Origins of political legitimacy. New York: McGraw-Hill Book Company.

Elchardus, M., \& Smits, W. (2002). Anatomie en oorzaken van het wantrouwen. Brussels: VUB Press.

Fornell, Claes. (22 Dec 2000). ACSI commentary: Federal Government scores. http://www.theacsi.org/government/govt-comm-00.html, accessed October 18, 2002.

Goodsell, C. T. (1985). The case for bureaucracy: A public administration polemic. Chatham: Chatham House Publishers Inc.

Government Performance and Results Act (1993). Government performance and results act of 1993. Washington, D.C.: U.S. Government Printing Office.

Kampen, J. K., \& Molenberghs, G. (2002). Vertrouwen in de regering en tevredenheid met het gevoerde beleid. In M. Swyngedouw and J. Billiet (eds.) De kiezer heeft zijn redenen: 13 juni 1999 en de politieke opvattingen van Vlamingen (pp. 179-191). 
Leuven: Acco.

Katz, D., Gutek, B. A., Kahn, R. L., \& Barton, E. (1977). Bureaucratic encounters: A pilot study in the evaluation of government services. Ann Arbor: Institute for Social Research.

Kettl, D. F. (1998). Reinventing Government: A fifth year report card. CPM 98-1. Washington, D.C.: Brookings Institution, Center for Public Management.

McAllister, I. (1999). The economic performance of governments. In P. Norris (ed.) Critical citizens: Global support for democratic governance (pp. 188-203). Oxford: Oxford University Press.

McCullagh, P. (1980). Regression models for ordinal data. Journal of the Royal Statistical Society, Series B (Methodological), 42(2), 109-142.

Meersseman, E., Billiet, J., Depickere, A., \& Swyngedouw, M. (2001). 1999 general election study Flanders - Belgium. Codebook and questionnaire. Leuven: ISPO.

National Partnership for Reinventing Government (Apr 2000). High impact agencies: Reinventing agencies that touch the most people. http://govinfo.library.unt.edu/npr/library/announc/hiapage3.html, accessed October $18,2002$.

National Partnership for Reinventing Government (12 Jan 2001). History of the National Partnership for Reinventing Government: Accomplishments, 1993 - 2000, A summary. http://govinfo.library.unt.edu/npr/whoweare/appendixf.html.

OECD (2000). Trust in government: ethics measures in OECD countries. Paris: OECD.

Pollitt, C., \& Bouckaert, G. (2000). Public management reform: A comparative analysis. Oxford: Oxford University Press.

Rothstein, B. (2001). Creating trust from above: social capital and institutional legitimacy. Paper presented at the ECPR joint session of workshops, Grenoble, Workshop 16, 
corruption, scandal and the contestation of governance in Europe.

Ryan, N. (2000). Public confidence in the public sector. A discussion paper prepared for the Office of the Auditor General of Western Australia.

Sims, H. (2001). Public confidence in government and government service delivery. Ottawa: Canadian Centre for Management Development.

Stoyko, P. (2002). Confidence and trust in government: An empirical survey of international experience. Ottawa: Canadian Centre for Management Development.

Tyler, T. R., \& Huo, Y. J. (2002). Trust in the law: Encouraging public cooperation with the police and the courts. New York: Russell Sage Foundation.

Van de Walle, S. (2004). Context-specific images of the archetypical bureaucrat: Persistence and diffusion of the bureaucracy stereotype. Public Voices, 1(1), 3-12.

Van de Walle, S., \& Bouckaert, G. (2003). Public service performance and trust in government: The problem of causality. International Journal of Public Administration, 26(8-9), 891-913.

Zaller, J. (1996). The nature and origins of mass opinion. Cambridge: Cambridge University Press. 
Author Note

Steven Van de Walle is researcher at the Public Management Institute, Katholieke Universiteit Leuven, Belgium. His research interests lie in citizens' perceptions of the public sector, trust in government and client satisfaction. He has published in International Review of Administrative Sciences, International Journal of Public Administration and Public Voices.

Jarl K. Kampen works as a statistician at the Public Management Institute, Katholieke Universiteit Leuven, Belgium. His specialisms include survey implementation and analysis, development of statistical models, and concept operationalisation in administrative science. Recent publications have appeared in Social Science Computer Review and British Journal of Mathematical and Statistical Psychology.

Geert Bouckaert is director of the Public Management Institute, Katholieke Universiteit Leuven. His research interests are in performance management, financial management and public sector reform. He has published extensively in the leading public administration journals. His recent books include Public Management Reform: An international comparison (with C. Pollitt, Oxford University Press, 2004). 


\section{Endnotes}

1. This research was made possible by a grant from the Programme for PolicyOriented Research of the ministry of the Flemish Community (PBO 99B/1/14).

2. HIAs in the NPR were: Animal and Plant Health Inspection Service, Food Safety and Inspection Service, Food and Nutrition Service, Forest Service, Census Bureau, U.S. and Foreign Commercial Service/International Trade Admin., Patent and Trademark Office, National Weather Service, Defence acquisition reform, Student financial assistance, Environmental Protection Agency, Federal Emergency Management Agency, General Services Administration, Food and Drug Administration, Administration for Children and Families, Health Care Financing Administration, National Park Service, Bureau of Land Management, Immigration and Naturalization Service, Occupational Safety and Health Administration, Office of Personnel Management, NASA, Small Business Administration, Social Security Administration, State Department Bureau of Consular Affairs, Federal Aviation Administration, Customs Service, IRS, Treasury Dept. Office of Domestic Finance/Financial Management Svc., U.S. Postal Service, Veterans Health Administration, Veterans Benefits Administration 


\section{Tables}

Table 1

Criteria for Selecting High-Impact Agencies

\begin{tabular}{|c|c|c|}
\hline Criteria & \multicolumn{2}{|l|}{ Meaning } \\
\hline Budget & \multicolumn{2}{|c|}{$\begin{array}{l}\text { What is the weight of the agency on the entire government budget? } \\
\text { What is the weight of a financial allocation, subsidy, allowance or tax in the } \\
\text { family budget? }\end{array}$} \\
\hline Frequency of use & $\begin{array}{l}\text { The higher the frequency of use, the } \\
\text { greater the impact that the service has } \\
\text { on one's image of government }\end{array}$ & Problem: how to assess "once in a \\
\hline Importance & $\begin{array}{l}\text { Daily use of public transportation } \\
\text { clearly has a different level of } \\
\text { importance than having to use the fire } \\
\text { department. Receiving a benefit two } \\
\text { months late has a different impact for } \\
\text { a poor family than for a rich one. }\end{array}$ & $\begin{array}{l}\text { lifetime" encounters. e.g. marriage, } \\
\text { death, ...: these have a very low } \\
\text { frequency of use, but this does not } \\
\text { reflect on the level of impact. }\end{array}$ \\
\hline Visibility & \multicolumn{2}{|c|}{$\begin{array}{l}\text { It is not use that determines high impact, but visibility. People should thus not } \\
\text { actually use the service, but see, hear, and observe it. }\end{array}$} \\
\hline Scandal & $\begin{array}{l}\text { Related to visibility. Emergence of a sc } \\
\text { may override all other bureaucratic enc }\end{array}$ & $\begin{array}{l}\text { andal with regard to one institution } \\
\text { ounters. }\end{array}$ \\
\hline
\end{tabular}


Deep Impact 28

Table 2

Ordinal Regression Results for "Satisfaction with the Functioning of Public Services" and

"Trust in Government"

\begin{tabular}{|c|c|c|}
\hline & $\begin{array}{c}\text { Satisfaction with the } \\
\text { functioning of public services } \\
\text { Estimate (Sig.) }\end{array}$ & $\begin{array}{c}\text { Trust in government } \\
\text { Estimate (Sig.) }\end{array}$ \\
\hline Gender & & \\
\hline Education & & $.223(.000)$ \\
\hline Age & & \\
\hline Income & & \\
\hline Urbanisation & & \\
\hline Police & $.362(.000)$ & $.368(.000)$ \\
\hline Courts & $.361(.000)$ & $.207(.029)$ \\
\hline Post & $.328(.000)$ & \\
\hline Primary education & & \\
\hline Refuse collection & & $.225(.010)$ \\
\hline Public transport & $.197(.017)$ & $.206(.018)$ \\
\hline Hospitals & $.219(.011)$ & \\
\hline Elderly care & & $.214(.004)$ \\
\hline Belgian Railways & & $-.296(.001)$ \\
\hline Public television & & \\
\hline $\begin{array}{c}\text { Municipal } \\
\text { administration }\end{array}$ & & \\
\hline Electricity company & & \\
\hline Police-officer & & \\
\hline Refuse collector & & \\
\hline Judge & & \\
\hline Teacher & $.185(.049)$ & \\
\hline Bus-driver & & \\
\hline Train conductor & & \\
\hline Mailman & & $.266(.011)$ \\
\hline Post office worker & $-.402(.000)$ & $-.298(.001)$ \\
\hline Prison ward & & \\
\hline Military & & \\
\hline Fire fighter & & \\
\hline Civil servant & $.267(.004)$ & $.265(.005)$ \\
\hline Politician & $.452(.000)$ & $.618(.000)$ \\
\hline $\mathrm{R}^{2}$ & .232 & .232 \\
\hline
\end{tabular}


Table 3

Government Staff is in General...

\begin{tabular}{l|ccccc}
\hline$\%$ & $\begin{array}{c}\text { Completely } \\
\text { Disagree }\end{array}$ & Disagree & not disagree & Agree & agree \\
& 1.2 & 10.7 & 26.7 & 58.4 & 3.0 \\
\hline Helpful & 1.3 & 10.7 & 34.8 & 49.9 & 3.3 \\
Friendly & 0.9 & 10.1 & 36.7 & 49.7 & 2.6 \\
Reliable & 8.2 & 41.1 & 33.8 & 15.7 & 1.1 \\
Fast & 1.8 & 20.1 & 40.0 & 36.3 & 1.8 \\
Comprehensible & 1.6 & 9.1 & 41.8 & 45.0 & 2.6 \\
Competent & 2.6 & 18.6 & 35.0 & 41.5 & 2.2 \\
Accessible & & & & & \\
\hline
\end{tabular}


Table 4

Linear Regression for Aspects of Service Delivery Satisfaction. Stepwise Selection

\begin{tabular}{|c|c|c|c|}
\hline & \multicolumn{2}{|c|}{ Unstandardized coefficients } & \multirow[t]{2}{*}{ Sig. } \\
\hline & $\mathrm{B}$ & Std. Error & \\
\hline (Constant) & -1.984 & .447 & .000 \\
\hline Municipal administration & .293 & .059 & .000 \\
\hline Civil servant & .302 & .061 & .000 \\
\hline Police-officer & .241 & .071 & .001 \\
\hline Courts & .197 & .052 & .000 \\
\hline Post & .181 & .053 & .001 \\
\hline Income & -.205 & .065 & .002 \\
\hline Military & .132 & .051 & .010 \\
\hline Refuse collection & .122 & .059 & .038 \\
\hline Public transport & .130 & .059 & .027 \\
\hline Fire fighter & -.152 & .067 & .023 \\
\hline Police & .138 & .064 & .030 \\
\hline
\end{tabular}

$\mathrm{R}^{2}=.343$ 
Table 5

Summary of Findings: Comparing Determinants of Trust. Satisfaction and Service Delivery Evaluations

\begin{tabular}{|c|c|c|c|}
\hline & $\begin{array}{c}\text { Trust in } \\
\text { government }\end{array}$ & $\begin{array}{l}\text { Satisfaction with } \\
\text { public services }\end{array}$ & $\begin{array}{c}\text { Service delivery } \\
\text { evaluation }\end{array}$ \\
\hline Politician & $\mathrm{X}$ & $\mathrm{X}$ & \\
\hline Police & $\mathrm{X}$ & $\mathrm{X}$ & $\mathrm{X}$ \\
\hline Civil servant & $\mathrm{X}$ & $\mathrm{X}$ & $\mathrm{X}$ \\
\hline Courts & $X$ & $\mathrm{X}$ & $\mathrm{X}$ \\
\hline Public transport & $\mathrm{X}$ & $\mathrm{X}$ & $X$ \\
\hline Post office worker & $\mathrm{X}$ & $\mathrm{X}$ & \\
\hline Mailman & $X$ & & \\
\hline Refuse collection & $\mathrm{X}$ & & $\mathrm{X}$ \\
\hline Education & $\mathrm{X}$ & & \\
\hline Elderly care & $X$ & & \\
\hline Belgian Railways & $\mathrm{X}$ & & \\
\hline Post & & $X$ & $\mathrm{X}$ \\
\hline Hospitals & & $X$ & \\
\hline Teacher & & $\mathrm{X}$ & \\
\hline Income & & & $X$ \\
\hline Municipal administration & & & $\mathrm{X}$ \\
\hline Police-officer & & & $\mathrm{X}$ \\
\hline \multicolumn{4}{|l|}{ Refuse collector } \\
\hline Military & & & $\mathrm{X}$ \\
\hline
\end{tabular}


Deep Impact 32

Fire fighter

X 
Figures

Figure 1

Trust in government and satisfaction with public services

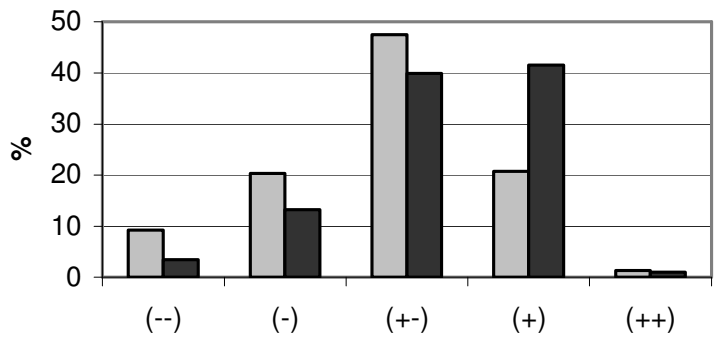

$\square$ trust in government $\square$ satisfaction public services 